that affects the nature of our activities, and where they can be carried out. To find out too how geography can help us understand patriarchy better, because spatial relations are one of the tools used in oppressing women. I feel confident that a feminist geography need not be an academic study, but can become one of the fronts on which we can attack patriarchy. It is a project that this book has valiantly begun and I am sorry that I am not in a position to know what ripples it is causing in university departments. I hope the next Feminist Review may carry some reports from the heart of the beast.

\section{Annie Neligan}

\section{Reference}

COCKBURN, Cynthia (1983) Brothers: Male Dominance and Technological Change London: Pluto.

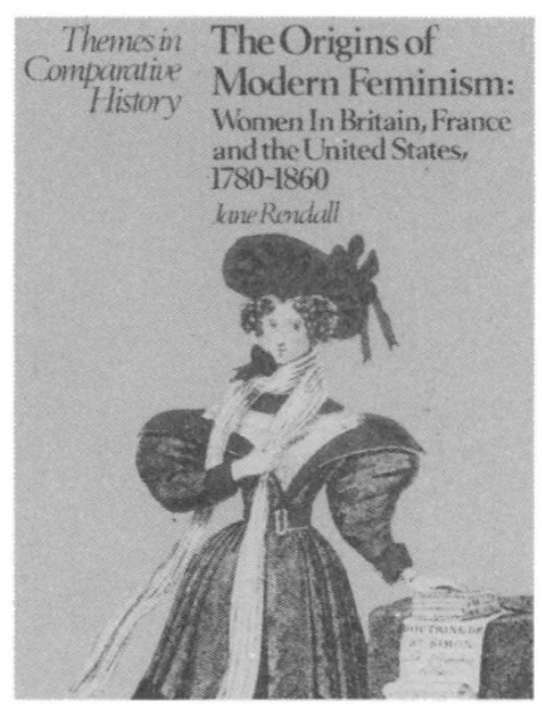

The Origins of Modern Feminism: Women in Britain, France and the United States, 1780-1860 Jane Rendall

Macmillan London 1985 ISBN 0-333-28910-5, ISBN 0-333-28901-3 $£ 20$ HC $£ 7.95$ Pbk.

Jane Rendall's ambitious project in this book is to trace the development of modern feminism in Britain, France and the United States between 1780-1860. She defines feminism as the theory which allowed women the right to claim their own place in society and the practice which made possible the coming together of women in groups and organizations to recognize and assert their common interests as a sex. As she rightly stresses, some aspects of that feminism are difficult for twentieth century feminists. The emphasis on 'equality in difference' and the attention paid to women's moral power have echoes in contemporary varieties of feminism and point us to unresolved problems of anatomy and destiny. But the language of religious enthusiasm and of separate spheres have limited resonance in modern capitalist society and require the imaginative reconstruction of a different social world in which women's needs and desires were articulated in substantially different ways from those we would now. recognize as feminist discourse. Feminism, we have come to learn, takes many different forms and Jane Rendall's book helps us to place and understand some of the late eighteenth and early nineteenth century feminisms, to wonder about their complex relation to our own beliefs and practices.

To tell the story of the origins of modern feminism Jane Rendall establishes its intellectual foundations in the re-workings of Enlightment ideals and the feminizing of evangelical religion. 
She then follows through the working of these beliefs in the fields of education, work, the home and the public sphere. Her attention focuses throughout on the ways in which women tried to identify what was happening to them in a period of rapid change, how they learnt to understand, to speak and, what is particularly important for her, to make available for themselves a 'language of association' which made possible collective organization and protest. In the $1790 \mathrm{~s}$, she argues, women were able to challenge the notion of male citizenship through the development of a 'rhetoric of republican motherhood'. Drawing on Enlightenment theories as to woman's nature, its susceptibility to feeling and imagination, its possession of distinctive moral qualities, thinkers such as Wollstonecraft were able to re-interpret womanhood in a more positive and inspirational way. The part which women would play in the new world would be inextricably linked to their role as mothers, their civic virtues would include good mothering, their moral fulfilment would come through the unification of their public and private duties.

While 'republican motherhood' was suffering serious defeats in the context of French and English political life in the later 1790s another equally importantinfluence was coming to bear on women. Hannah More has long been castigated as the arch conservative of the 1790 s, the enemy of Wollstonecraft, the architect of separate spheres. But as Ray Strachey recognized many years ago in The Cause, her pioneering work on English feminism, the legacy of More was a deeply ambiguous and contradictory one. Evangelical religion combined an insistence on the

\section{$m / f_{m \infty 10}$}

France Britain $\quad$ America

Conference Issue - Papers and Discussion

The Forms of Historical Feminism Geneviève Fraisse

The Women's Liberation Movement in Socialist France Françoise Ducrocq

The Feminine Superego Catherine Millot

Feminism. Film Theory and the Bachelor Machines Constance Penley

Women and the Labour Market Bea Campbell

£2.75 inland and Europe, $\$ 4.00$ USA, $\$ 3.25$ elsewhere. Payable to $\mathrm{m} / \mathrm{f}$ 24 Ellerdale Road, London NW3 6BB England 
proper place of women as within the family with a high evaluation of women's moral worth, an emphasis on women's positive and unique qualities, and a recognition of their reforming mission in the world. As Jane Rendall argues, evangelical religion offered women through its language and imagery, through its emphasis on individual conversion, through its encouragement of religious life both within and beyond the family, a powerful framework, potentially both limiting and expanding, with which to make sense of changing structures and experiences. Within evangelical religion there were both conservative and radical elements and its legacy was deeply contradictory.

The use made by women of these two traditions is followed through in an examination of the development of feministideas and practices in the spheres of education and work, the worlds of the private and the public. The arguments about improving women's education, whether to make them better mothers or better paid workers, and the attempts to improve facilities and training for teachers are outlined. The changes in the organization of work and the beginnings of organized female protest as to hours and conditions are described, together with the creation of alternative co-operative schemes. The differential meaning of 'home' and 'private' according to nation and class are recorded and the attempts within the middle class, in the wake of evangelicalism, to extend the domestic sphere, and consequently women's influence. The impressive record of working class women's militancy in England particularly, through the. Female Reform Associations and the Chartist movement, both tinged with the legacy of 'republican motherhood', is traced. The determined efforts of middle class women in England and the United States to assert their rights to carry their evangelizing mission beyond the home to the prisons, the workhouses, the brothel and the public house, to challenge male authority and female propriety in the name of sisterhood is evoked. Finally, Jane Rendall suggests, by the mid nineteenth century, there was a recognized feminist movement in both Britain and the United States. It was very small and predominantly middle class, but it was there, with all the potential to be something more, to cross class, race and national barriers and become a powerful political force.

The book brings together an impressive range of material and bears witness to the range and breadth of feminist history over the last fifteen years. Jane Rendall has made full use of the variety of secondary sources available and for this reason alone it should be required reading for anyone interested in women's history. The footnotes are a joy if you want to know about any of her topics from the Enlightenment to the relation between abolitionism and feminism. The text is full of fascinations. Take the Proclamation of the National Convention in Paris in 1793 when revolutionaries instructed women as to how they should behave in the new republic:

Women! do you want to be republicans? Love, follow and teach the laws which recall your husbands and children to the exercise of their rights; honour the great deeds that may be done for your country, to show that they will be done for you; be simple in your dress, hardworking in your home; never go to popular assemblies with the wish to speak there, but so that your presence may encourage your children.

This anti-feminism amongst the progressives in France had to compete with that of the reactionaries, as, for example, in the decree of the Second Empire which formally prohibited women from political 
commentary or being the directors of newspapers between 1852-81. Another astonishing glimpse is of evangelical missionaries attempting to inculcate American Indians with the proper relationships between the sexes, insisting that the men should be farmers and the women housewives and mothers. All of this is combined with an attempt to take on board the varieties in women's experience associated with class, ethnic, regional and national differences, a daunting project indeed.

Jane Rendall is trying to do at least two major tasks at once and I think this results in some tensions in the book. Since there was no general history available of the changing lives of women in this period in the three countries she deals with she is at one and the same time constructing such a history and weaving from it the web of the origins of feminism. At points the two tasks are in conflict and leave us with a somewhat unsatisfactory account. In the chapter on work, for example, she is trying to cover French peasant society, the American south and slavery, the American frontier and the development of industrial and agrarian capitalism in England, to name only some of the necessary elements. Not surprisingly it is almost impossible to create a coherent pattern out of these disparate economies and societies with their different expectations of women and their different material bases. The effect can be to lose specific narratives and textures. For example, without providing a fuller account of the transformation of the sexual division of labour within industrial capitalism, the continuing importance of familial relations within the labour process and the re-assertion of male dominance through skill it is hard to make sense of the vital history of sexual antagonism whether in the London trades or the Northern textile factories.

This relates to a second problem for me which is about the comparative method. Too much knowledge is assumed of the different social structures of the three countries and sometimes it is hard to hold on to the specific national histories we are dealing with. General readers can be expected to have a basic political framework but how many of us have an adequate knowledge of the economic structures of the three countries to be able to grasp vital distinctions in class formation, for example? I would have found a brief background sketch on this, admittedly a tall order, a very helpful introduction. But the difficulties go beyond background knowledge. At the end of the book the absence of a theory of the political and the economic and its relation to feminism surfaces when Jane Rendall pulls together the comparison between the feminisms of England, France and the United States. (Incidentally Scottish, Welsh and Irish readers might justifiably remark that it would have been better to confine the title to England since the vast majority of the material deals with the English experience.) In explaining the differences between French feminism, which is characterized as weaker and more backward, and its Anglo-American counterparts, she has recourse to the different character of the French bourgeoisie from that of England and the United States, the relative weakness of the French working class because of the persistence of peasant farming and late industrial development and the particular nature of the French church and state. Since feminism owed so much to evangelical religion in England and the States the absence of an equivalent development within Catholicism is obviously crucial. All these strike me as fascinating issues and points of comparison yet only Catholicism was addressed in the text. I was sorry that these came up at the end rather than providing part of the 
framework for the substantive analysis.

This takes me to a final and related point. Men are pretty absent from the book, except for those men who supported feminists, such as John Stuart Mill, or those men who were especial enemies such as Proudhon. In a sense this is hardly surprising in a history of the origins of feminism. But it has the effect of displacing feminism from other social processes, other political debates, other ways of conceptualizing the relations between men and women. There are tantalizing references to the relation between feminism and political economy, for example, but these are left unexplored. But they need exploring.
Jane Rendall ends her book by arguing that the demand for female autonomy and the necessity for association were the hallmarks of feminist theory and practice in this period. But, it could be suggested, the demand for individual autonomy and the recognition of the need for collective action are two of the fundamental aspects of liberalism in this period also, things which middle class and working class men were also fighting for. In the end the attempt to separate off women's history from men's history leaves us with other problems to solve. Still, Jane Rendall has taken us a significant step forward.

\section{Catherine Hall}

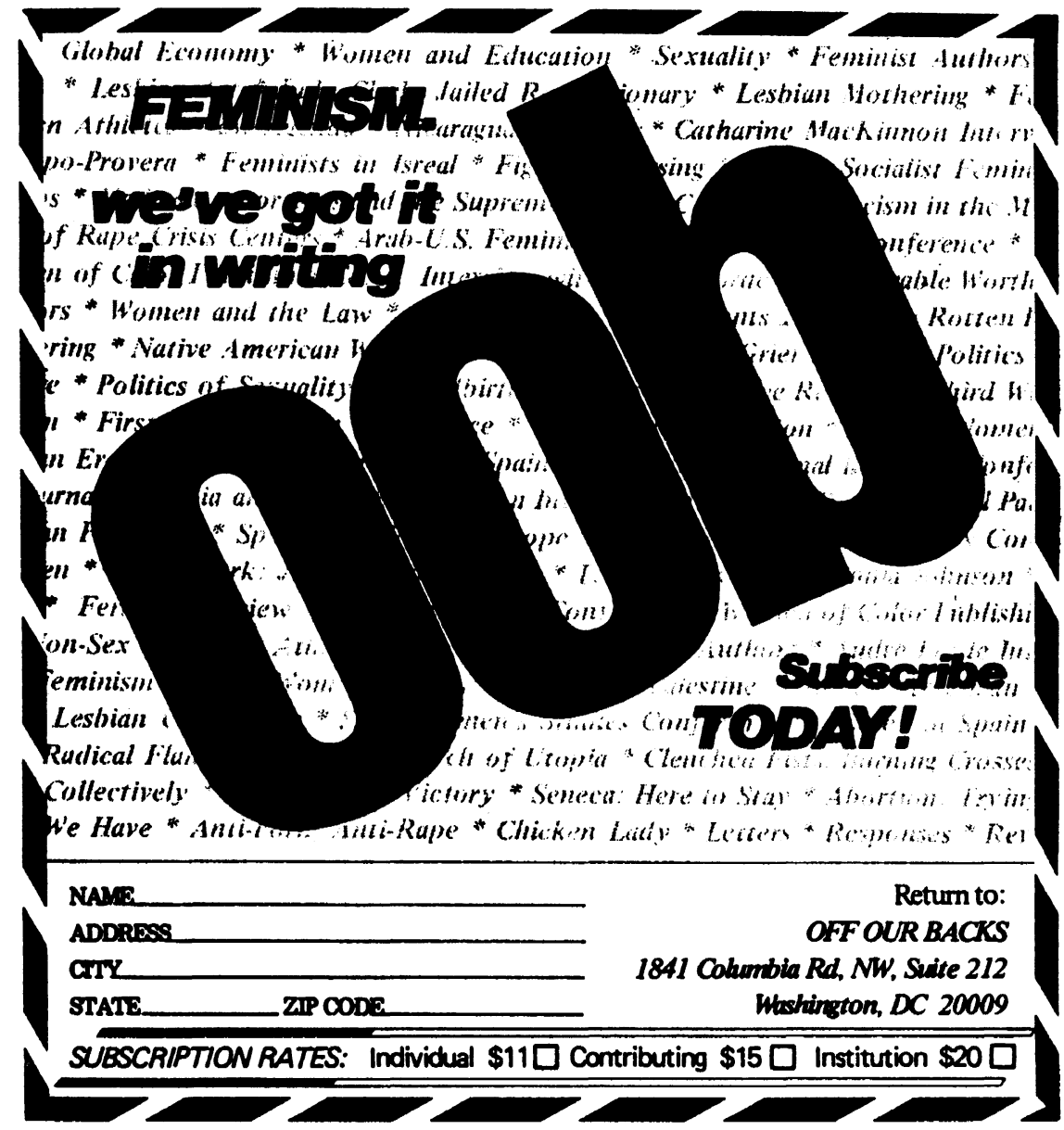

